\title{
Recent changes in spring snowmelt timing in the Yukon River basin detected by passive microwave satellite data
}

\author{
K. A. Semmens and J. M. Ramage \\ Lehigh University, Bethlehem, Pennsylvania, USA \\ Correspondence to: K. A. Semmens (kalese@gmail.com) \\ Received: 11 September 2012 - Published in The Cryosphere Discuss.: 18 October 2012 \\ Revised: 30 April 2013 - Accepted: 6 May 2013 - Published: 5 June 2013
}

\begin{abstract}
Spring melt is a significant feature of high latitude snowmelt dominated drainage basins influencing hydrological and ecological processes such as snowmelt runoff and green-up. Melt duration, defined as the transition period from snowmelt onset until the end of the melt refreeze, is characterized by high diurnal amplitude variations (DAV) where the snowpack is melting during the day and refreezing at night, after which the snowpack melts constantly until depletion. Determining trends for this critical period is necessary for understanding how the Arctic is changing with rising temperatures and provides a baseline from which to assess future change. To study this dynamic period, brightness temperature $\left(T_{\mathrm{b}}\right)$ data from the Special Sensor Microwave Imager (SSM/I) 37 V-GHz frequency from 1988 to 2010 were used to assess snowmelt timing trends for the Yukon River basin, Alaska/Canada. Annual $T_{\mathrm{b}}$ and DAV for 1434 Equal-Area Scalable Earth (EASE)-Grid pixels ( $25 \mathrm{~km}$ resolution) were processed to determine melt onset and melt refreeze dates from $T_{\mathrm{b}}$ and DAV thresholds previously established in the region. Temporal and spatial trends in the timing of melt onset and melt refreeze, and the duration of melt were analyzed for the 13 sub-basins of the Yukon River basin with three different time interval approaches. Results show a lengthening of the melt period for the majority of the sub-basins with a significant trend toward later end of melt refreeze after which the snowpack melts day and night leading to snow clearance, peak discharge, and green-up. Earlier melt onset trends were also found in the higher elevations and northernmost subbasins (Porcupine, Chandalar, and Koyukuk rivers). Latitude and elevation displayed the dominant controls on melt timing variability and spring solar flux was highly correlated with melt timing in middle $(\sim 600-1600 \mathrm{~m})$ elevations.
\end{abstract}

\section{Introduction}

Arctic air temperature has increased at roughly double the global rate for the past several decades with more recent warming appearing strongest in winter and spring, critical seasons for snow accumulation and melt, ice breakup, and first leaf/bloom (IPCC, 2007; Schwartz et al., 2006; Kittel et al., 2011). Higher latitudes are especially sensitive to climatic change due to various positive feedbacks such as from snow-albedo and sea ice interactions resulting in Arctic amplification (Kittel et al., 2011; Overland et al., 2011). Climate models project increases in average air temperatures of $3^{\circ} \mathrm{C}$ for the Arctic by 2040 , increases in precipitation in mid to high latitudes leading to overall deeper arctic snow cover, and increases in snowmelt and runoff for cold regions (Adam et al., 2009). The Arctic snowpack integrates effects of changes over several months, so predicted impacts of climate change are most strongly expressed, resulting in predictions of the strongest shifts to the hydrological cycle in the early spring melt period (Nijssen et al., 2001). For instance, Regonda et al. (2004) found shifts (advancing) in the timing of streamflow for snowmelt-dominated basins in the western United States over $50 \mathrm{yr}$, as well as a decrease in snow water equivalent and increase in the fraction of precipitation as rain instead of snow. These trends reflect increases in spring temperatures, and increases in winter temperatures and precipitation leading to diminished snowpack (Mote, 2003).

It is hypothesized that such shifts/increases will be reflected in the timing of snowmelt onset and the end of the melt refreeze, between which is a transitional period defined here as the "melt duration period" where the snowpack is melting during the day and refreezing at night as detected by passive microwave sensors highly sensitive to the presence 
of liquid water. The timing of this high diurnal variation period of melt refreeze (when the snow is fully saturated and the snowpack isothermal) affects the progression of meltwater through a basin, as its timing is closely followed by the snow off date (which is usually a few days to weeks later depending on maximum snow accumulation), freshet timing, and peak snowmelt runoff, and is closely linked to green-up and growing season start (Cayan et al., 2001; Schwartz et al., 2006; Wang et al., 2011). Further, shifts in the timing of melt refreeze and freeze-thaw processes may have nonlinear effects on ecosystems once thresholds are surpassed (Kittel et al., 2011). Some shifts are already being identified such as spring snowmelt in northern Alaska advancing since the 1960s due to warmer temperatures and diminished snowfall, of importance to the surface radiation budget due to the resulting changes in albedo (Stone et al., 2002).

Further, for high latitude drainage basins, snowmelt onset, peak runoff, and associated flooding are the most important and significant hydrologic events each year (Kane, 1997; Rouse et al., 1997; Yang et al., 2009). Melt timing has a critical influence on the annual hydrological cycle: depending on the prevailing temperature patterns, the snowmelt period may be longer, snow gradually depleted, and runoff spread out with earlier melt, or snowmelt may be rapid, synchronous, and peak runoff high with delayed melt onset (Woo and Thorne, 2006). Thus changes in snowmelt timing and streamflow seasonality impact the availability of water resources in snowmelt-dominated basins, affecting populations that rely on seasonal snowpacks for their water supply (Barnett et al., 2005). Snowmelt timing and related runoff may also affect and be affected by wildfire occurrence whose frequency, intensity, and associated landscape changes are altered by the changing climate (Westerling et al., 2006; Shakesby and Doerr, 2006).

Assessment of melt timing trends provides evidence for changes in snowmelt and associated runoff, which may be indicative of hydrologic shifts (Serreze et al., 2000; Yang et al., 2002, 2009). Snowmelt trends for the pan-Arctic as detected by microwave brightness temperatures $\left(T_{\mathrm{b}}\right)$ from the Scanning Multichannel Microwave Radiometer (SMMR) and the Special Sensor Microwave Imager (SSM/I) have been previously assessed for 1979-2008 (Tedesco et al., 2009). The melt onset and melt end dates were found to have significant negative trends with melt starting $0.5 \mathrm{~d} \mathrm{yr}^{-1}$ earlier and ending $1 \mathrm{~d} \mathrm{yr}^{-1}$ earlier over the past $30 \mathrm{yr}$, thus showing a shortened melt season of $0.6 \mathrm{~d} \mathrm{yr}^{-1}$ (Tedesco et al., 2009). Melt onset and snow-off dates for the pan-Arctic were also detected from enhanced resolution SeaWinds scatterometer QuikSCAT data from 2000-2005 using a melt algorithm that identifies multiple melt events, their duration and intensity, and comparing the differences between daily time series radar data and the previous five day average (Wang et al., 2008). Results from the QuikSCAT melt detection revealed that melt onset occurred in the middle to the end of March for boreal forest areas, increased with latitude, and was later over high elevation areas and for years with a cold spring season. Melt end dates were later over lake-rich areas and had more interannual variability than onset dates, while melt duration was longer for areas with deeper snow cover (Wang et al., 2008). An integrated pan-Arctic melt onset date dataset from active and passive microwave satellites further elucidated melt progression over various land types and determined that elevation, tree fraction and latitude largely explained mean melt onset date in the terrestrial Arctic (Wang et al., 2011). Additionally, thaw transitions and timing of spring thaw across Canada and Alaska determined from daily radar backscatter (QuikSCAT) agreed well with river discharge increases illustrating the hydrological significance of this critical period (Rawlins et al., 2005).

Here we investigate spatial and temporal trends in date of snowmelt onset and end of melt refreeze, as well as duration of melt, detected utilizing passive microwave $T_{\mathrm{b}}$ data from the SSM/I. The analysis focuses on the Yukon River basin (YRB) for the years of record 1988 to 2010. The YRB is one of the largest basins in North America, stretching from northwestern Canada to the Bering Sea through Alaska and drains $853300 \mathrm{~km}^{2}$ crossing from northwestern Canada through central Alaska, covering several ecoregions, and discharging an annual mean discharge of $6400 \mathrm{~m}^{3} \mathrm{~s}^{-1}$ of water and 60 million tons of sediment at its mouth to the Bering Sea annually (Brabets et al., 2000). Most of the 13 subbasins of the Yukon can be characterized by a subarctic nival regime with snowmelt driving runoff, but some have significant glacier runoff, particularly the White and Tanana River basins (Brabets et al., 2000; Woo et al., 2008).

Given the rising temperature trends and projections for this area, the basin is vulnerable to permafrost degradation, making it ideal for studying its sensitivity to warming temperatures (Walvoord and Striegl, 2007). For the YRB, modeling studies suggest earlier snowmelt timing of longer duration, diminished snow cover extent, and increased runoff and erosion due to permafrost thawing (Walvoord and Striegl, 2007; Hay and McCabe, 2010). A water balance model forced with IPCC climate simulations to project potential hydrological responses to climate change in the YRB for the 21st century indicate increased runoff (largest for May to July), later snow accumulation start, and earlier snowmelt start with the largest temperature changes in the winter (Hay and McCabe, 2010).

This study, focusing on one river basin (Fig. 1), as opposed to previous pan-Arctic studies, provides a more detailed regional investigation of the trends and governing factors of the changes in melt duration in spring. It is hypothesized that the most significant differences will occur among basins based on their latitude and range of elevation, since temperature varies with elevation which effects melt (Bell and Moore, 1999). The analysis will focus on sub-basins and elevation classes of $200 \mathrm{~m}$ intervals (based on average elevation of each pixel) within each sub-basin.

Elevation was found to relate to snowmelt for the Sierra Nevada where 1500 to $2100 \mathrm{~m}$ elevations contributed 


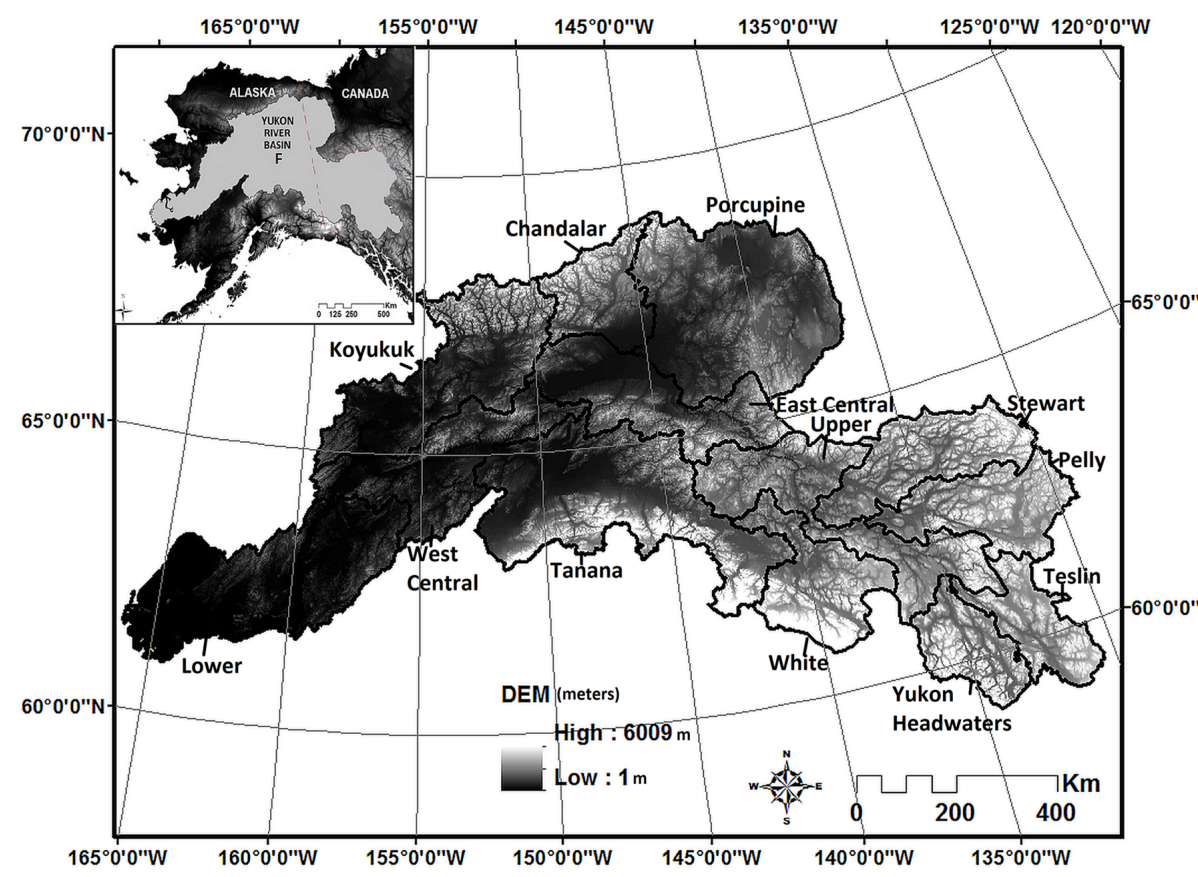

Fig. 1. Map overview of Yukon River basin (upper left) and 30 arc second digital elevation model (DEM) showing the range of elevations throughout the basin with the 13 sub-basins outlined and labeled. DEM created from GTOPO30 data from USGS EROS Data Center (Long and Brabets, 2002).

$10-15 \%$ of snowmelt, 2100 to 3000 m elevations $40-60 \%$,

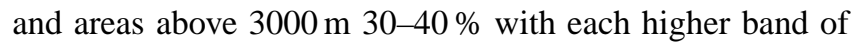
elevation melting out 2 to 3 weeks later than the band below (Rice et al., 2011). Further evidence of elevation dependency is seen in earlier shifts in the timing of peak streamflow that vary by elevation in the western United States with the strongest trends at elevations less than $2500 \mathrm{~m}$ (Regonda et al., 2004), in earlier spring pulse onset dates found in lower elevation basins, and in strong trends toward earlier flows (advances in hydrograph center of mass) for middle elevation gauges in western North America (Stewart et al., 2005). It can also be seen in the declining trends in April 1 snow water equivalent (SWE) in the Pacific Northwest that are elevation dependent (Mote, 2003, 2006; Mote et al., 2005). The fraction of precipitation accumulation from snow (snowfall equivalent/precipitation, SFE/P) has declined across the Pacific Northwest with the largest trends near the elevation of the climatological freezing level (near $1000 \mathrm{~m}$ ), coinciding with increasing trends in positive degree days for low elevation mountains (Abatzoglou, 2011). Correlations of atmospheric circulation patterns (climate indices as proxies) with SWE have also been found to be dependent on elevation (Mote, 2006), and the influence of the Pacific-North American pattern on the SFE/P is a nonlinear function of elevation (Abatzoglou, 2011). These studies suggest the relationship between elevation and temperature is reflected in various snow related parameters and are expected to be revealed in the snowmelt timing parameters investigated here.

\section{Data and methods}

Melting snow is detectable by passive microwave sensors because the presence of liquid water within a snowpack increases its emissivity, thus increasing $T_{\mathrm{b}}$, which is a function of the surface temperature $\left(T_{\mathrm{s}}\right)$ and emissivity $(\varepsilon)$ of the material $\left(T_{\mathrm{b}} \sim \varepsilon T_{\mathrm{S}}\right)$. Therefore there is a significant difference in $T_{\mathrm{b}}$ between wet (emits close to that of a blackbody) and dry snow (Chang et al., 1975; Ulaby et al., 1986). Wet snow grains result in an increase in loss tangent (quantification of dissipation of electromagnetic energy of a dielectric material) and thus a scattering albedo of near zero and emissivity near unity, which explains the rapid increase in $T_{\mathrm{b}}$ for melting snow (Chang et al., 1976). Higher frequency wavelengths are sensitive to the shallow depths of snowpack while lower frequencies can penetrate deeper. Here the $37 \mathrm{GHz}$ vertically polarized wavelength is used due to its high sensitivity to liquid water in the snowpack (Ramage et al., 2006). Previous studies have shown snow cover distribution and snowmelt timing are adequately measured by passive microwave sensors daily, in all weather conditions (Hall et al., 1991; Mote et al., 1993; Drobot and Anderson, 2001; Ramage and Isacks, 2002; Wang et al., 2005; Ramage et al., 2006; Apgar et al., 2007; Tedesco, 2007; Tedesco et al., 2009). 


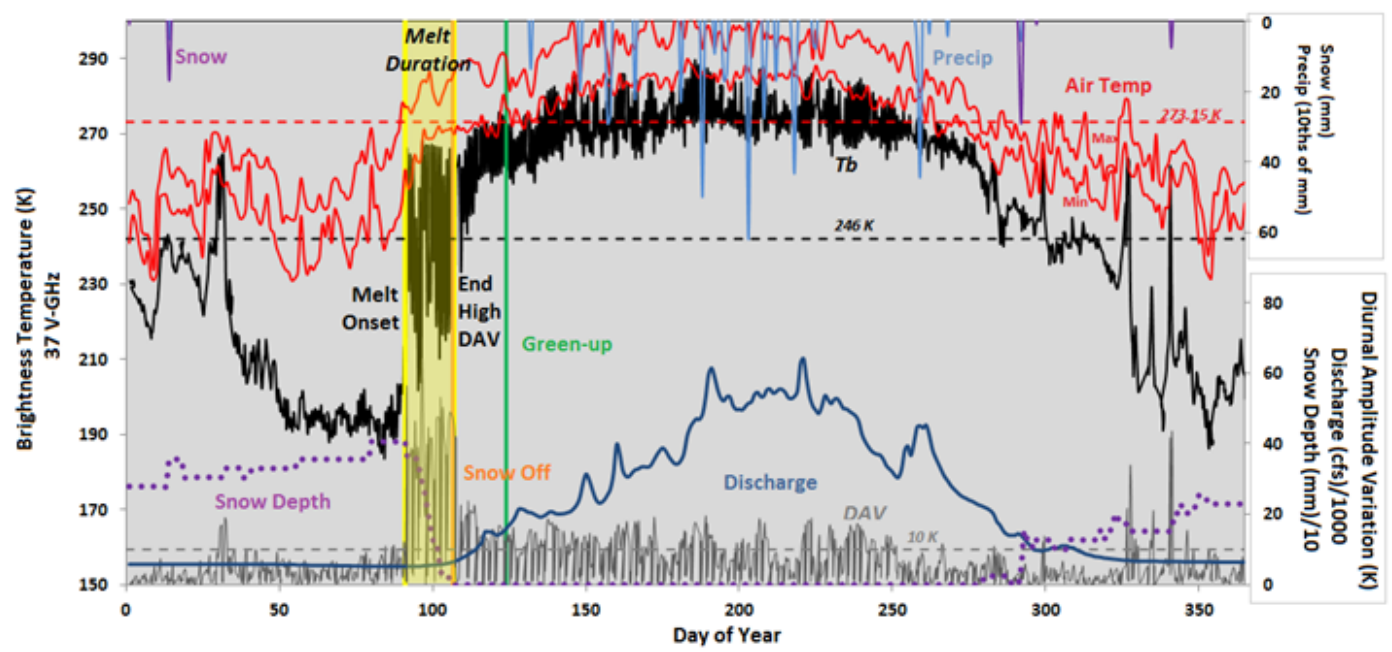

Fig. 2. Illustration of the relation of melt timing variables and processes. Brightness temperatures $\left(T_{\mathrm{b}}\right)$ and diurnal amplitude variation (DAV)(from SSM/I $37 \mathrm{~V}-\mathrm{GHz}$ ) in 2007 for the Fairbanks pixel (see label $F$ in overview map Fig. 1) in the Tanana River sub-basin of the Yukon River. $T_{\mathrm{b}}$ and DAV thresholds (set as $T_{\mathrm{b}}>246 \mathrm{~K}$ and $|\mathrm{DAV}|>10 \mathrm{~K}$; Ramage et al., 2006) determine dates of melt onset and end of melt refreeze (end of high DAV), which are defined as when thresholds are met for more than three of five consecutive days. The end high DAV coincides with snow off, steady increase in discharge, and green-up (17 days later). Discharge data are from Tanana River at Fairbanks USGS 15485500 National Water Information System. Green-up data are from Bonanza Creek Long Term Ecological Research database (Euskirchen, 2007). Precipitation, snow, snow depth, and air temperature are from the Global Historical Climatology Network (GHCND) from Fairbanks International Airport $\left(64.81667^{\circ} \mathrm{N}, 147.86667^{\circ} \mathrm{W}\right)$.

SSM/I data provided by the National Snow and Ice Data Center (NSIDC) in the form of Level 3 Equal-Area Scalable Earth (EASE)-Grid Brightness Temperatures gridded data for Northern Hemisphere projection have a resolution of $37 \times 28 \mathrm{~km}^{2}$ gridded to an EASE-Grid $25 \times 25 \mathrm{~km}^{2}$ with two observations per day at overpass times around 08:30 and 18:30 PST (Pacific Standard Time) (Armstrong et al., 1994). For a continuous data record from 1988 to 2010, SSM/I data from DMSP (Defense Meteorological Satellite Program) F8, F11, F13, and F17 satellites were combined. Specifically, years 1988-1991 were from F8 (local equator crossing time; 06:17 LCT), years 1992-1995 were from F11 (18:25 LCT), years 1996-2007 were from F13 (17:43 LCT), and years 2007-2010 were from F17 (17:31 LCT). While others have used linear regression equations to correct data between the different satellites, in general the biases due to a switch in satellites are minimal and not statistically significant, with regression coefficients affecting data by generally less than $0.5 \%$ (Abdalati et al., 1995; Stroeve et al., 1998; Cavalieri et al., 1999; Meier et al., 2001). There is high consistency among the SSM/Is' brightness temperatures suggesting differences are minimal (Dai and Che, 2009). Additionally, intercalibration is best when there is a long overlap between satellites, preferably at least a year so that seasonal differences can be accounted for, thus adjustments based on short overlapping time periods may be less accurate and introduce bias (Stroeve et al., 1998). Based on these findings and on a manual overview of the data, no correction was deemed necessary given the risk of introduction of new unknown bias.
Others have employed a similar approach using unadjusted time series of radiometer brightness temperature data (for example, Takala et al., 2011).

SSM/I data and the technique for detecting snowmelt timing has been previously established and validated in the upper YRB using $37 \mathrm{GHz}$ vertically polarized data (Ramage et al., 2006) and has been found to correlate well with higher resolution Advanced Microwave Scanning Radiometer-EOS (AMSR-E) derived snowmelt onset (Apgar et al., 2007). The twice-daily observations enable the calculation of the running difference between the ascending and descending brightness temperature values termed the diurnal amplitude variation or DAV, which is interpreted as a proxy of the dynamism of the snowpack as the liquid water content changes (Ramage and Isacks, 2002). High DAV values, especially for $37 \mathrm{GHz}$ sensitive to the top centimeter of snowpack, indicate when the snowpack is melting during the day and refreezing at night (Ramage et al., 2006). The end of this melt refreeze period is of interest because its timing is closely followed by snow clearance, freshet, peak runoff, and other significant ecological processes such as green-up. This timing indicates that the snowpack is saturated and isothermal and melt occurs both day and night until the accumulated snowpack is gone, thus it is not the end of melt but rather a transition point when melt moves from intermittent to active. When the DAV is high there is a large contrast between the day and night, whereas a low value indicates less fluctuation (it is either always wet or always frozen). Figure 2 illustrates how 
the timing of the melt refreeze period relates to other significant events (i.e., snow clearance, discharge, and green-up).

Snowmelt onset was determined from SSM/I data $(37 \mathrm{GHz}$ vertically polarized) when $T_{\mathrm{b}}$ is greater than $246 \mathrm{~K}$ and DAVs are above $\pm 10 \mathrm{~K}$, thresholds previously developed and ground validated (Ramage and Isacks, 2002; Ramage et al., 2006). Melt onset (and end high DAV/melt refreeze) was defined as the first (and last) date when at least three of five consecutive days meet the $T_{\mathrm{b}}$ and DAV thresholds described above. Melt duration was the length in days from melt onset to end of melt refreeze. The three of five day algorithm has proven accurate based on manual cross checking of observations and correspondence with estimates from earlier work, and allows the melt onset and melt refreeze end to be automatically detected for large regions such as the YRB. A similar approach was previously utilized with QuikSCAT (Quick Scatterometer) where melt onset was identified when the difference was greater than a threshold for three or more consecutive days and the intensity calculated as the accumulated decrease in radar cross section in relation to the five day mean (Wang et al., 2008). A similar threshold based passive microwave melt detection approach was previously applied successfully over a wide spatial domain in the pan-Arctic study by Tedesco et al. (2009). In addition, the passive microwave derived melt timing signal (onset and melt refreeze) was corroborated by auxiliary datasets, including ground station data (Global Historical Climate Network), model results from SnowModel (Liston and Hiemstra, 2011), QuikSCAT backscatter change (Bartsch et al., 2010), and North American Regional Reanalysis (NARR) data (Semmens et al., 2013).

It is important to note that there are some limitations with the methodology. The derived melt timing metrics are measurements of the snow surface and does not account for variation of melt percolation within the snowpack or stratigraphic dynamics such as described in Marsh and Woo (1984). Further, the sources of error for this approach include the coarse resolution of the SSM/I data, which does not account for subgrid variability in vegetation and elevation. However, the resolution of the DEM used is much larger than the SSM/I pixel size, minimizing the effect of this uncertainty. We assume that the same thresholds apply across all sub-basins, areas, and SSM/I sensors (Ramage et al., 2006). If a pixel has a significant subportion melting (but not all) it will be detected as wet. Additionally, these methods assume the terrain is relatively homogeneous (the majority of the basin $(\sim 73 \%)$ is wetland, plains, and lowlands) and the snowmelt signal is not distorted by land cover and topography, thus there is some uncertainty due to vegetation, mixed pixels, subgrid variability, and high relief (Mätzler et al., 1998). With regard to snow water equivalent, Foster et al. (2005) found errors to be highest with deep snow, dense forests, and fast growing crystals with topography having less of an effect on the passive microwave retrievals than vegetation. Dong et al. (2005) found errors associated with snow pack mass and distance to open water, among other sources. While these studies focus on SWE, they are illustrative of the sources of error and uncertainty working with passive microwaves (e.g., Foster et al., 2005, and references therein). In the present study, pixels close to the coast in the Lower Yukon sub-basin were excluded from the analysis to reduce errors associated with coastal regions.

Trends in the date of melt onset and end of melt refreeze were calculated from linear regression with trend significance determined using the $p$ value from the two-tailed student's $t$ test after testing for normal distribution and autocorrelation. The fraction of variance explained is also reported $\left(R^{2}\right)$. These trends were determined from average dates of melt timing based on sub-basin as well as elevation class with elevation binned by $200 \mathrm{~m}$ intervals $(0-200 ; 3001-3200$, etc.). Pixels were grouped into elevation class based on the average elevation determined from a 30 arc second digital elevation map (Long and Brabets, 2002). SSM/I derived melt timing trends were calculated for (1) the whole period 19882010, (2) a $7 \mathrm{yr}$ moving average within the whole period, (3) an increasing trend length starting at 1988 with trend end years ranging from 1998 to 2010, and (4) the period 20032010 in order to compare to the AMSR-E dataset (results are similar and not shown in the interest of space). The variable trend end year approach was successfully utilized in previous studies of sea ice extent (Kay et al., 2011) and for investigating individual streamflow patterns in watersheds (Zhang et al., 2010). While the Mann-Kendall (MK) test has been predominately used in previous studies of streamflow trends (Burn and Hag Elnur, 2002; Burn et al., 2010), here regression and $t$ test analyses were conducted in lieu of the MK test in order to be able to characterize the pattern of the trend, its rapidity and when and how the trend changes. Further, based on trend analysis of annual streamflow in Turkey, the parametric $t$ test and MK test can be used interchangeably, with the $t$ test being more powerful for normally distributed datasets (Önöz and Bayazi, 2003).

To determine possible processes contributing to the trends, several parameters were compared to the melt timing dataset. Solar flux at $10.7 \mathrm{~cm}$ wavelength, measured by solar radio telescope as the emissions due to solar activity accounting for the distance between the Earth and sun (National Research Council of Canada, 2011), was analyzed against the average melt onset, average end of melt refreeze date, and average melt duration for each elevation class and subbasin. Further, anomalies from the 1981-2010 climatology for air temperature at $850 \mathrm{mb}$ and sea level pressure from the NCEP/NCAR (National Centers for Environmental Prediction / National Center for Atmospheric Research) reanalysis (Kalnay et al., 1996) were used as proxies for atmospheric circulation patterns to compare to temporal trends for correlative and multiple regression analysis. For each dependent parameter (melt onset, end of melt refreeze, and melt duration) multiple regression was calculated using five independent variables - average elevation, latitude, longitude, and 


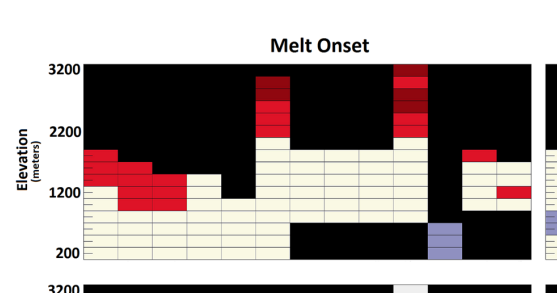

Trend by Basin and Elevation 1988-2010
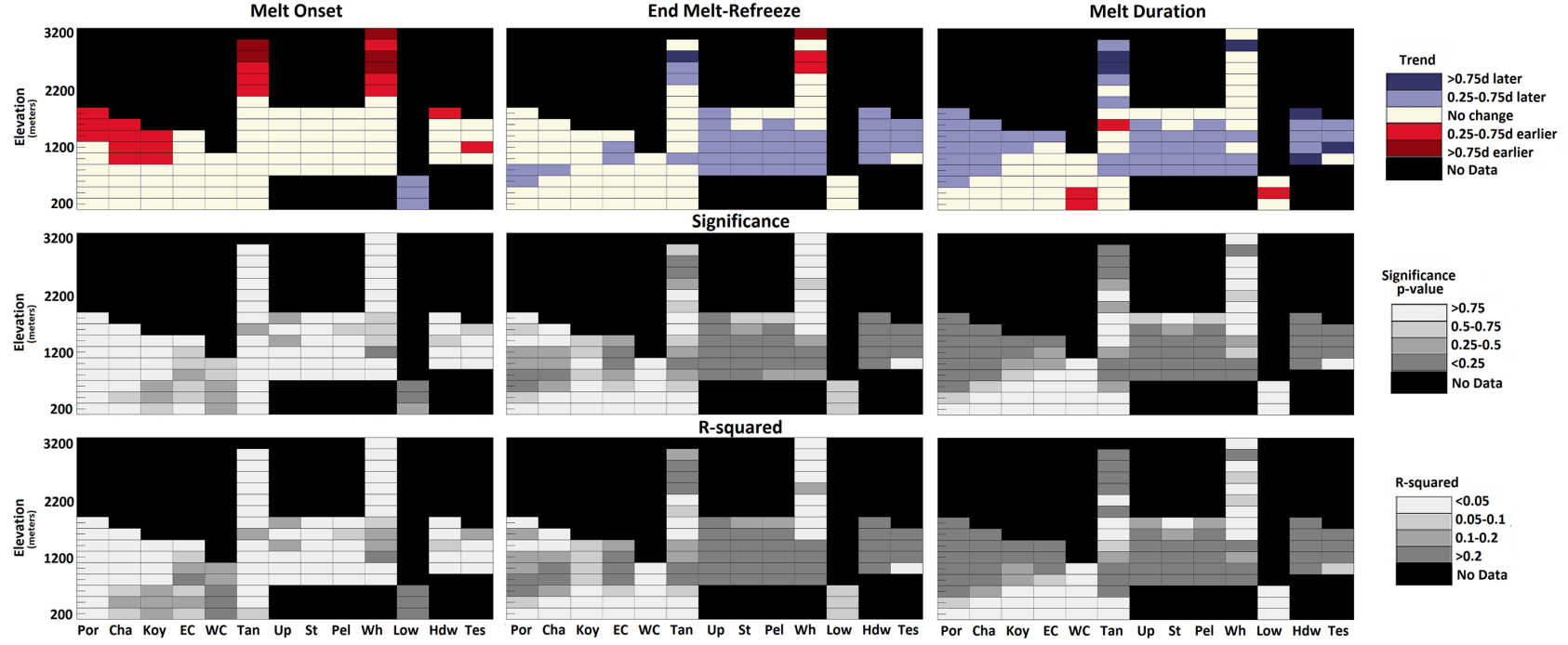

Fig. 3. Spatial and temporal trends (each basin (x-axis) and elevation class (y-axis)) for melt onset (left column), end melt refreeze (center column), and melt duration (right column). In each column, top plots are the direction and magnitude of trend (red is earlier melt and blue is later melt timing). Middle plots are the significance of the trends $-p$ value of student's $t$ test (darker is more significant). Bottom plots are the $R^{2}$ values (darker is higher $R^{2}$ ). Black indicates no data for that basin and elevation. Basins are arranged from highest to lowest latitude (left to right). Labels for sub-basins (shown in Fig. 1) are as follows: Por $=$ Porcupine, Cha $=$ Chandalar, Koy $=$ Koyukuk, EC $=$ East Central, WC $=$ West Central, Tan $=$ Tanana, Up $=$ Upper, St $=$ Stewart, Pel $=$ Pelly, Wh $=$ White, Low $=$ Lower, Hdw $=$ Yukon Headwaters, Tes $=$ Teslin.

composite (October to April for each year) anomalies for sea level pressure and air temperature at $850 \mathrm{mb}$.

\section{Results}

Three interval approaches were investigated to assess the trends in melt onset, end of melt refreeze, and melt duration from the $23 \mathrm{yr} \mathrm{SSM/I} \mathrm{record.} \mathrm{Each} \mathrm{approach} \mathrm{is} \mathrm{shown} \mathrm{with}$ trend direction depicted in color, followed by significance (from $p$ value) and $R^{2}$ for fraction of variance explained (Figs. 3-5). First, to distinguish spatial patterns of trends, the entire length of the data record ( $23 \mathrm{yr}$ ) is shown for each sub-basin among the range of elevations in $200 \mathrm{~m}$ intervals (Fig. 3). A distinct pattern of earlier melt onset (Fig. 3, left column) occurs in the higher (over $1000 \mathrm{~m}$ ) elevations and in the northernmost sub-basins that are generally underlain by continuous permafrost; however, the trends are not significant. The majority of elevations and basins show no significant change in onset with the exception of slightly later onset in the Lower Yukon. This may reflect the more maritime climate or the prevalence of wetlands, which can affect the $T_{\mathrm{b}}$ signature. In contrast to melt onset, end of melt refreeze trends (Fig. 3, center column) are toward later timing, are significant, and have high $R^{2}$ values. The later trends tend to be in the middle $(\sim 600-1600 \mathrm{~m})$ elevations and latitudes such as in the Upper, Stewart, Pelly, White, Teslin, and Yukon headwater sub-basins. Longer melt duration trends are significant and occur throughout the YRB with the exception of no change in the lowest elevations (Fig. 3, right column). Melt duration is a function of both earlier melt onset and later melt refreeze, depending on the sub-basin and elevation class.

To better understand the temporal variability of the detected trends, time intervals were systematically increased with variable end years, starting with a ten year period from 1988 to 1998 and extending to a $23 \mathrm{yr}$ period from 1988 to 2010 (Fig. 4). Earlier trends (not significant but large $R^{2}$ ) occur for melt onset but as the time interval increases in length these are muted to essentially no change in onset (Fig. 4, left column), suggesting alternating subtrends. In contrast, end of melt refreeze shows a later trend for the majority of the basins throughout most of the time intervals investigated which are, in general, statistically significant (Fig. 4, center column). Melt duration shows a trend toward longer duration for the majority of the basins and is statistically significant (Fig. 4, left column). These trends persist regardless of the length of interval, indicative of robustness.

To get a sense of the subtrends affecting the longer-term trends, a $7 \mathrm{yr}$ moving interval window was used for the analysis shown in Fig. 5. Each column shows the trend for a $7 \mathrm{yr}$ time period starting with each year from 1988 to 2003 (Fig. 5). Other interval windows (10,5, and 3) were also considered and showed similar results; $7 \mathrm{yr}$ is shown because it is the least noisy. There is a distinct pattern from earlier melt onset ( $>0.75 \mathrm{~d} \mathrm{yr}^{-1}$ earlier) in the beginning of the $23 \mathrm{yr}$ period to later onset in the middle of the period and back to earlier onset at the end of the period for the majority of the 

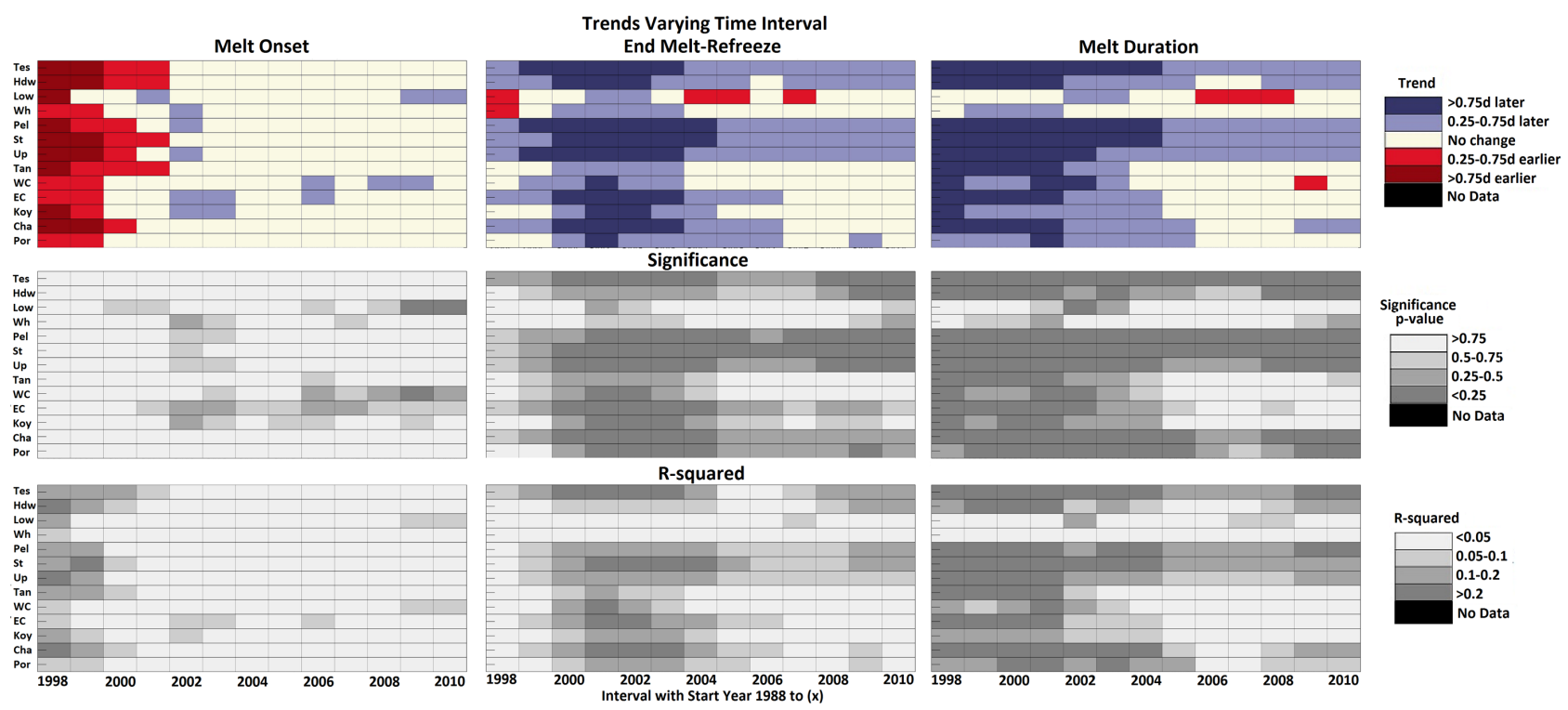

Fig. 4. Trends by varying time intervals (x-axis) for each basin (y-axis) for melt onset (left column), end melt refreeze (center column), and melt duration (right column). Trend, significance, and $R^{2}$ plots and keys are as in Fig. 3. In each plot, the $\mathrm{x}$-axis columns are time intervals starting with the $10 \mathrm{yr}$ period from 1988 to 1998 and each subsequent column is a year longer than the preceding.

basins (Fig. 5, left column). The two main exceptions are the lower elevation West Central and Lower Yukon sub-basins that have a later onset trend in more recent years. The earlier onset trends are not statistically significant in contrast to the significant later onset trends, and both tend to have high $R^{2}$ values. The trend for end of melt refreeze is earlier (but not significant) in the beginning of the time series that transitions to a later (and highly significant, high $R^{2}$ ) trend, then a nonsignificant (but high $R^{2}$ ) earlier trend for years 1998 2001, and finally a significant later trend in the last two periods (Fig. 5, center column). Stemming from the onset and end of melt refreeze trends, the melt duration trends exhibit a lengthening, then a shortening (nonsignificant but high $R^{2}$ ), and back to lengthening at the end of the time series (Fig. 5, left column). These alternations suggest a subtrend cyclic pattern that may be related to climatic patterns, though the brevity of the dataset precludes such determinations.

Multiple regression with average elevation, latitude, longitude, and composite (October to April for each year) anomalies from NCEP/NCAR Reanalysis (Kalnay et al., 1996) for sea level pressure and air temperature at $850 \mathrm{mb}$ explain $47.4 \%$ of the variance for end of melt refreeze timing, $60.7 \%$ of variance for melt onset timing, and $38 \%$ of the variance for melt duration. In particular, for end of melt refreeze, average elevation was most strongly correlated (0.44), followed by longitude $(0.21)$. For melt onset, latitude was most strongly correlated $(0.32)$ followed by average elevation (0.29). For melt duration, the strongest correlation was with latitude $(-0.34)$ followed by elevation $(0.21)$. All correlations were significant with $p$ values $<0.0001$. These results support the initial hypothesis that elevation exhibits a dominant control on melt timing (albeit more strongly for melt refreeze than melt onset) within the sub-basins.

Figure 6a demonstrates the strong correlation between solar flux $(10.7 \mathrm{~cm}$ wavelength, National Research Council of Canada, 2011), melt onset timing, basin, and elevation. Correlations between the average solar flux for April (when typical melt onset occurs) are shown; correlations over 0.41 are significant at the 0.05 level (using a two-tailed correlation significant test). Specifically, the majority of mid to high elevations have significant positive correlations with solar flux with the most significant correlations found in the high latitude Chandalar, Koyukuk, and Porcupine River sub-basins. This suggests there may be evidence of an $11 \mathrm{yr}$ cycle of melt, the periodicity of which appears in power spectrum analyses that are not included in the publication due to uncertainties introduced with the short length of the dataset. In contrast, there is not as significant a correlation between end of melt refreeze and solar flux in May (when typical end of melt refreeze occurs) (Fig. 6b), indicating that other processes influence the signal, most likely snowpack properties and accumulation, precipitation, and large-scale atmospheric circulation patterns. Melt duration (Fig. 6c) shows a similar lack of significant correlation with average solar flux with the exception of mid elevations in the Chandalar and Koyukuk (which is likely due to the significant correlations seen in their melt onset). Others have also found latitude and elevation to be important factors influencing mean melt onset date (Wang et al., 2011). Additionally, trends in SWE were found to be elevation dependent (suggesting temperature as the dominating factor) (Mote, 2003), and hydroclimatological variables were 

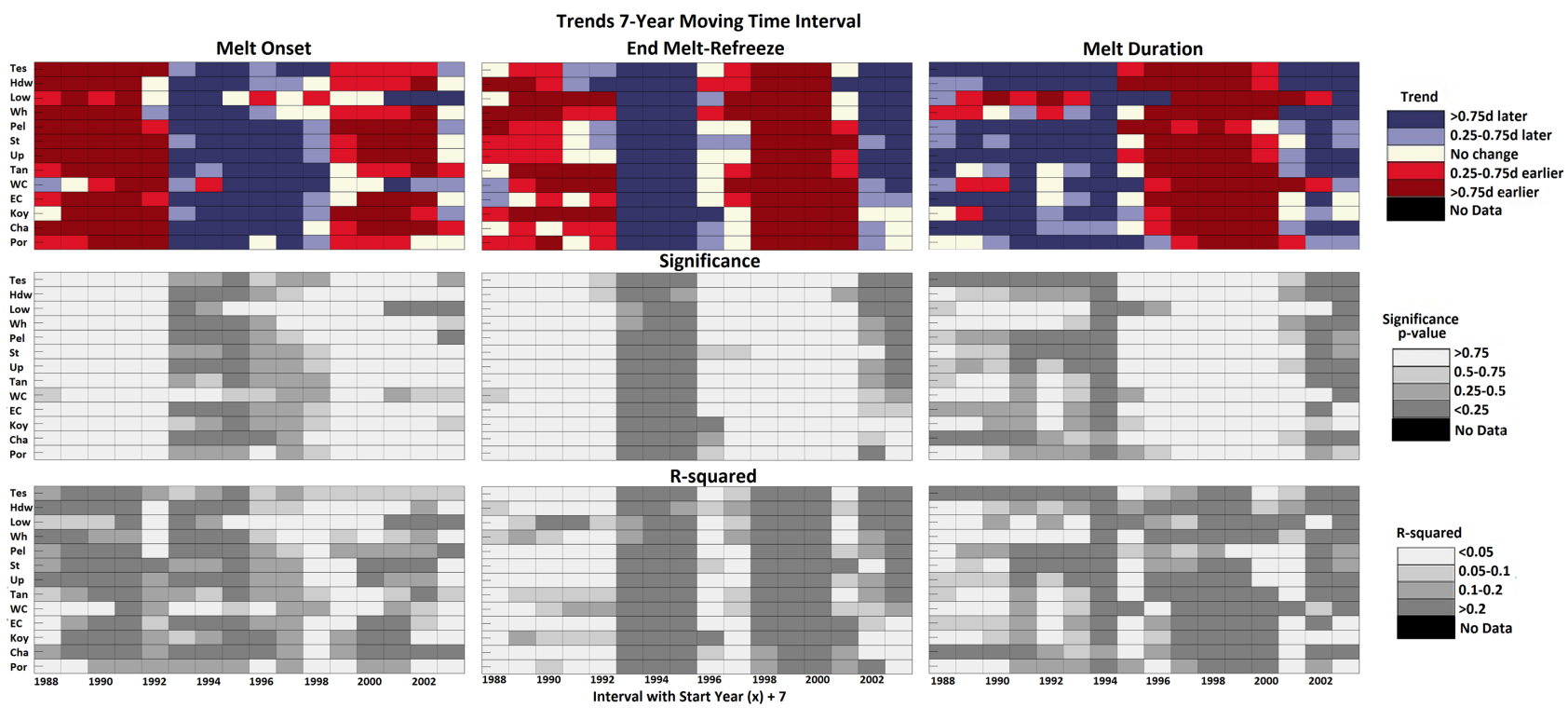

Fig. 5. Trends by 7 yr moving window intervals (x-axis) for each basin (y-axis) for melt onset (left column), end melt refreeze (center column), and melt duration (right column). Trend, significance, and $R^{2}$ plots and keys are as in Fig. 3 . In each plot, the x-axis columns are $7 \mathrm{yr}$ time intervals starting with years 1988 to 2003.

found to exhibit elevation gradients in a majority of studies (Regonda et al., 2004; Rangwala and Miller, 2012).

\section{Discussion and conclusions}

Trend analysis of passive microwave SSM/I-derived snowmelt onset, end of melt refreeze, and melt duration in the sub-basins of the YRB from 1988 to 2010 reveals significant lengthening of melt duration throughout much of the basin with earlier melt onset in high elevations and the northernmost basins (Porcupine, Chandalar, and Koyukuk rivers) and significant later end of melt refreeze in the intermediate elevations $(\sim 600$ to $1600 \mathrm{~m})$ and latitudes. This is a significant finding for ecosystems because middle elevations' vegetation greenness has been found to be strongly correlated with snowmelt variability and snow accumulation (Trujillo et al., 2012). Mountain ecosystems are particularly sensitive to water and climate elevational variations especially at the switch from middle to high elevation, when the system turns from water limited to energy limited (Trujillo et al., 2012). In addition, the lengthening of the melt refreeze period is reported as a current concern for local communities due to the longer duration of the spring shoulder season when river bank instability makes transportation via river difficult (Hennessey et al., 2011).

Melt onset is most strongly correlated with spring solar flux especially in high elevations and northern sub-basins. The effect of solar cycles at middle and high latitudes was also found by Tomasino and Valle (2000) in their analysis of multiple historical hydrometeorological datasets. The spatial variability of the melt timing trends may reflect variations from incoming solar radiation or differential warming rates dependent on elevation. Previous studies have found strong correlations of April SWE and winter temperatures with temperature sensitivity dependent on elevation (Mote, 2006). Surface air temperature lapse rates can vary significantly on a daily and seasonal basis but there tends to be steeper rates, meaning more of a decrease in temperature with height, in summer in contrast to winter, during the day, with higher levels of solar radiation, and with warm air masses (Blandford et al. 2008). Despite this seasonal variability, the average environmental lapse rate constant $\left(6.5^{\circ} \mathrm{C}_{\text {per km}}{ }^{-1}\right)$ may be adequate for maximum temperatures over larger scales (temporal and spatial) (Blandford et al., 2008). For an elevationdependent snowmelt modeling study of basins in Britain, Bell and Moore (1999) used the wet adiabatic lapse rate of $5.9^{\circ} \mathrm{C}$ per $\mathrm{km}^{-1}$. Specific regional lapse rates for the YRB are not published but arctic inversions are known to occur in late October to early March, which is outside the general window for the timing of spring snowmelt onset and melt refreeze investigated in this study.

Several high elevation climate records have shown temperature changes (especially seasonal warming rates) greater than the global average, suggesting future climate change may be more apparent in these areas (Beniston et al., 1997). More warming is expected to affect the snowpack with spring SWE growing more sensitive to temperature, affecting even high elevations (Mote, 2006). Others suggest the $0^{\circ} \mathrm{C}$ isotherm locates the areas of strongest warming rates possibly a result of snow/ice albedo feedbacks (Pepin and Lundquist, 2008; Rangwala and Miller, 2012). Still, others 


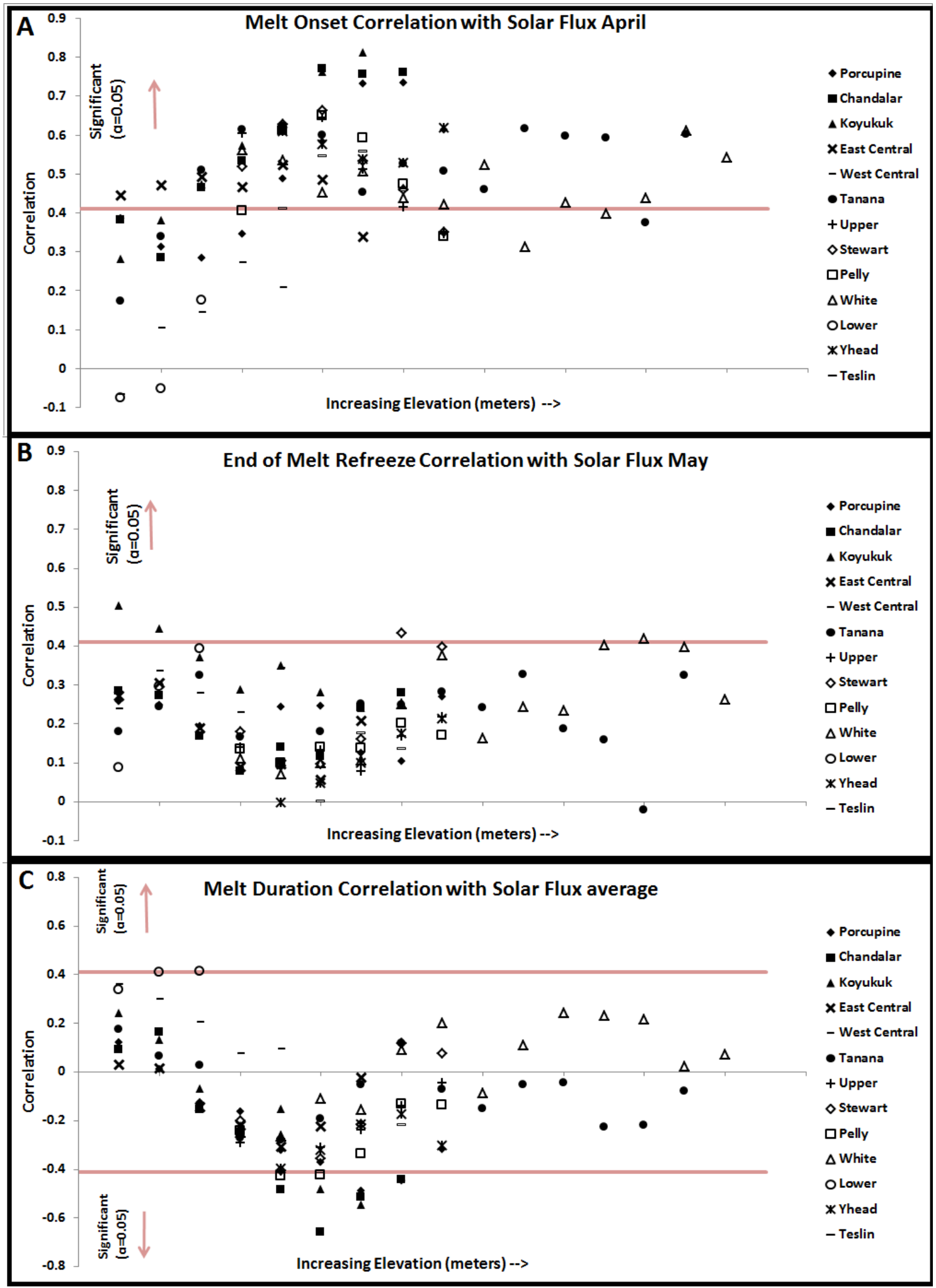

Fig. 6. Correlations of melt timing variables and solar flux for each basin and elevation class. (A) Correlation (y-axis) for melt onset and solar flux in April by basin and elevation (x-axis). (B) Correlation (y-axis) for end of melt refreeze and solar flux in May. (C) Correlation (y-axis) for melt duration and average solar flux. For all plots correlations greater than 0.41 and less than -0.41 are significant at the $5 \%$ level. Solar flux data (10.7 cm wavelength) are from the National Research Council of Canada. 
suggest mid-elevation systems are most sensitive to temperature increases and changes to snowmelt and accumulation (Trujillo et al., 2012). While an "elevation-dependent" climate response is observed and modeled in many studies, there is large variability both spatially and temporally due to the complexity of mountain systems (Rangwala and Miller, 2012). The prevalence of snow in high elevations may have a buffering effect on changes while lower elevation's snow variability may suggest climate change susceptibility (Rice et al., 2011), both factors that can influence the melt timing trends presented here. In addition, atmospheric circulation patterns and increasing fractions of precipitation falling as rain instead of snow may be factors affecting the trends in melt timing.

In this study, varying the time period interval for trend analysis enabled elucidation of interannual variability and subtrends possibly related to circulation patterns; however, given the short data record we cannot conclude any causal relationship. Several studies have detected solar activity and El Niño periodicities in other natural processes from temperature to rainfall to streamflow (Fu et al., 2012, and references therein). In particular, Fu et al. (2012) found 11 and $22 \mathrm{yr}$ periodicities corresponding to solar activity in streamflow records (longer than $90 \mathrm{yr}$ ) from southern Canada, as well as shorter 3-4 yr periodicities correlating to El Niño ( $2-7 \mathrm{yr}$ band). While a much longer dataset is needed, the results from the research presented here provide a baseline from which to assess future climatic change and suggest that a similar investigation of the influence of solar activity and El Niño on snowmelt timing is worthwhile for determining spatial and temporal patterns of the effects of climate change on cryospheric and hydrologic processes.

Future work will include extending the time series for a more robust trend and periodicity analysis, as well as extending the spatial domain. Earlier years (1978 to 1987) from the Scanning Multi-channel Microwave Radiometer (SMMR) could not be included without substantial interpolation (which introduces uncertainty and error) due to the temporal continuity needed to compute the DAV. In situ measurements to capture elevational gradients of melt and temperature will also be pursued to provide further validation of the findings presented here.

In summation, the melt timing trend variability for the YRB reflects multiple influencing factors, however, solar flux and elevation are dominant controls and the overall pattern is toward a longer melt duration for the spring snowmelt transition period which has significant implications for snowmelt runoff and associated flooding, as well as green-up and first leaf dates. Additionally, the trend analysis highlights the importance of choice of time period for analysis and the need to investigate varying time intervals in order to understand the dynamics of trends.
Acknowledgements. SSM/I data provided by National Snow and Ice Data Center. NCEP Reanalysis data provided by the NOAA/OAR/ESRL PSD, Boulder Colorado, USA. Solar flux data are from the National Resource Council of Canada. We are grateful to J. E. Kay for discussions about the trend analyses. Semmens is supported by NASA Headquarters under the NASA Earth and Space Science Fellowship - Grant "NNX10AP14H".

Edited by: A. Nolin

\section{References}

Abatzoglou, J. T.: Influence of the PNA on declining mountain snowpack in the Western United States, Int. J. Climatol., 31, 1135-1142, 2011.

Abdalati, W., Steffen, K., Otto, C., and Jezek, K. C.: Comparison of brightness temperatures from SSMI instruments on the DMSP F8 and F11 satellites for Antarctica and the Greenland ice sheet, Int. J. Remote Sens., 16, 1223-1229, 1995.

Adam, J. C., Hamlet, A. F., and Lettenmaier, D. P.: Implications of global climate change for snowmelt hydrology in the twenty-first century, Hydrol. Proc., 23, 962-972, 2009.

Apgar, J. D., Ramage, J. M., McKenney, R. A., and Maltais, P.: Preliminary AMSR-E Algorithm for Snowmelt Onset Detection in Subarctic Heterogeneous Terrain, Hydrol. Proc., 21, 1587-1596, 2007.

Armstrong, R. L., Knowles, K. W., Brodzik, M. J., and Hardman, M. A.: DMSP SSM/I Pathfinder Daily EASE-Grid Brightness Temperatures (1988-2010), Boulder, Colorado USA: National Snow and Ice Data Center, 1994.

Barnett, T. P., Adam, J. C., and Lettenmaier, D. P.: Potential impacts of a warming climate on water availability in snow-dominated regions, Nature, 438, 303-309, 2005.

Bartsch, A., Kumpula, T., Forbes, B. C., and Stammler, F.: Detection of snow surface thawing and refreezing in the Eurasian Arctic with QuikSCAT: implications for reindeer herding, Ecol. Appl., 20, 2346-2358, 2010.

Bell, V. A. and Moore, R. J.: An elevation-dependent snowmelt model for upland Britain, Hydrol. Proc., 13, 1887-1903, 1999.

Beniston, M., Diaz, H. F., and Bradley, R. S.: Climatic change at high elevation sites: an overview, Clim. Change, 36, 233-251, 1997.

Blandford, T. R., Humes, K. S., Harshburger, B. J., Moore, B. C., Walden, V. P., and Ye, H.: Seasonal and synoptic variations in near-surface air temperature lapse rates in a mountainous basin, J. Appl. Meteorol. Climatol., 47, 249-261, 2008.

Brabets, T. P., Wang, B., and Meade, R. H.: Environmental and hydrologic overview of the Yukon River Basin, Alaska and Canada, USGS Water-Resources Investigations Report 99-4204, Anchorage, Alaska, 2000.

Burn, D. H. and Hag Elnur, M. A.: Detection of hydrologic trends and variability, J. Hydrol., 255, 107-122, 2002.

Burn, D. H., Sharif, M., and Zhang, K.: Detection of trends in hydrological extremes for Canadian watersheds, Hydrol. Proc., 24, 1781-1790, 2010.

Cavalieri, D. J., Parkinson, C. L., Gloersen, P., Comiso, J. C., and Zwally, J. H.: Deriving long-term time series of sea ice cover from satellite passive-microwave multisensory data sets, J. Geophys. Res., 104, 15803-15814, 1999. 
Cayan, D. R., Kammerdiener, S. A., Dettinger, M. D., Caprio, J. M., and Peterson, D. H.: Changes in the onset of spring in the western United States, Bull. Am. Meteorol. Soc., 82, 399-415, 2001.

Chang, A. T. C. and Gloersen, P.: Microwave emission from dry \& wet snow, Operational Applications of Satellite Snow Cover Observations, NASA, Washington, DC, 399-407, 1975.

Chang, A. T. C., Gloersen, P., Schmugge, T., Wilheit, T. T., and Zwally, H. J.: Microwave emission from snow and glacier ice, J. Glaciol., 16, 23-39, 1976.

Dai, L. and Che, T.: Cross-platform calibration of SMMR, SSM/I and AMSR-E passive microwave brightness temperature, Sixth International Symposium on Digital Earth: Data Processing and Applications, Proc. of SPIE 7841, 784103, 2009.

Dong, J., Walker, J. P., and Houser, P. R.: Factors affecting remotely sensed snow water equivalent uncertainty, Remote Sens. Environ., 97, 68-82, 2005.

Drobot, S. and Anderson, M.: An improved method for determining melting onset dates over Arctic sea ice using scanning multichannel microwave radiometer and Special Sensor Microwave/Imager data, J. Geophys. Res., 106, 24033-24049, 2001.

Euskirchen, E.: Greenup values for interior Alaska 1976 Present, Bonanza Creek LTER - University of Alaska Fairbanks, BNZ:300, http://www.lter.uaf.edu/data_detail.cfm? datafile_pkey=_300, 2007.

Foster, J. L., Sun, C., Walker, J. P., Kelly, R., Chang, A., Dong, J., and Powell, H.: Quantifying the uncertainty in passive microwave snow water equivalent observations, Remote Sens. Environ., 94, 187-203, 2005.

Fu, C., James, A. L., and Wachowiak, M. P.: Analyzing the combined influence of solar activity and El Nino on streamflow across southern Canada, Water Resour. Res., 48, W05507, doi:10.1029/2011WR011507, 2012.

Hall, D. K., Sturm, M., Benson, C. S., Chang, A. T. C., Foster, J.L., Garbeil, H., and Chacho, E.: Passive microwave remote and in situ measurements of arctic and subarctic snow covers in Alaska, Remote Sens. Environ., 38, 161-172, 1991.

Hay, L. E. and McCabe, G. J.: Hydrologic effects of climate change in the Yukon River Basin, Clim. Change, 100, 509-23, 2010.

Hennessey, R., Jones, S., Swales, S., and Duerden, F.: Dawson Climate Change Adaptation Plan, Revised Edition. Northern Climate ExChange, Yukon Research Centre, Yukon College, Whitehorse, YT, 64 pp., 2011.

IPCC: Climate Change 2007: Impacts, Adaptation and Vulnerability, Contribution of Working Group II to the Fourth Assessment Report of the Intergovernmental Panel on Climate Change, edited by: Parry, M. L., Canziani, O. F., Palutikof, J. P., van der Linden, P. J., and Hanson, C. E., Cambridge University Press, Cambridge, UK, 976 pp., 2007.

Kalnay, E., Kanamitsu, M., Kistler, R., Collins, W., Deaven, D., Gandin, L., Iredell, M., Saha, S., White, G., Woollen, J., Zhu, Y., Chelliah, M., Ebisuzaki, W., Higgins, W., Janowiak, J., Mo, K.C., Ropelewski, C., Wang, J., Leetmaa, A., Reynolds, R., Jenne, R., and Joseph, D.: NCEP/NCAR 40-yr reanalysis project, Bull. Amer. Meteor. Soc., 77, 437-470, 1996.

Kane D. L.: The impact of Arctic hydrologic perturbations on Arctic ecosystems induced by climate change, Global Change and Arctic Terrestrial Ecosystems, Ecological Studies 124, SpringVerlag, New York, 63-81, 1997.
Kay, J. E., Holland, M. M., and Jahn, A.: Inter-annual to multidecadal Arctic sea ice extent trends in a warming world, Geophys. Res. Lett., 38, L15708, doi:10.1029/2011GL048008, 2011.

Kittel, T. G. F., Baker, B. B., Higgins, J. V., and Haney, J. C.: Climate vulnerability of ecosystems and landscapes on Alaska's North Slope, Reg. Environ. Change, 11, S249-S264, 2011.

Liston, G. E. and Hiemstra, C. A.: The changing cryosphere: panarctic snow trends (1979-2009), J. Climate, 24, 5691-5712, 2011.

Long, D. and Brabets, T. P.: Coverage YUK_DEM National Stream Quality Accounting Network (NASQAN) Yukon River Basin, Canada and Alaska Basin, Yukon River, 2002.

Marsh, P. and Woo, M. K.: Wetting Front Advance and Freezing of Meltwater Within a Snow Cover 1: Observations in the Canadian Arctic, Water Resour. Res., 20, 1853-1864, 1984.

Mätzler, C., Hiltbrunner, D., and Standley, A.: Relief effects for passive microwave remote sensing, WP330, SNOW-TOOLS, Res. Report No. 98-3, 1998.

Meier, W. N., Khalsa, S. J. S., and Savoie, M. H.: Intersensor calibration between F-13 SSM/I and F-17 SSMIs near-real-time sea ice estimates, IEEE Trans. Geosci. Remote Sens., 49, 3343 3349, 2011.

Mote, P. W.: Trends in snow water equivalent in the Pacific Northwest and their climatic causes, Geophys. Res. Lett., 30, 1601, doi:10.1029/2003GL017258, 2003.

Mote, P. W.: Climate-driven variability and trends in mountain snowpack in Western North America, J. Climate, 19, 6209-6220, 2006.

Mote, P. W., Hamlet, A. F., Clark, M. P., and Lettenmaier, D. P.: Declining mountain snowpack in Western North America, Bull. Am. Meteorol. Soc., 86, 39-49, 2005.

Mote, T. L., Anderson, M. R., Kuivinen, K. C., and Rowe, C. M.: Passive microwave-derived spatial \& temporal variations of summer melt on Greenland ice sheet, Ann. Glaciol., 17, 233-238, 1993.

National Research Council of Canada: $10.7 \mathrm{~cm}$ Solar Flux Data, ftp://ftp.ngdc.noaa.gov/STP/SOLAR_DATA/SOLAR_RADIO/ FLUX/Penticton_Observed/monthly/MONTHLY.OBS, 2011.

Nijssen, B., O’Donnell, G. M., Hamlet, A. F., and Lettenmaier, D. P.: Hydrologic sensitivity of global rivers to climate change, Clim. Change, 30, 143-175, 2001.

Önöz, B. and Bayazi, M.: The power of statistical tests for trend detection, Turkish J. Eng. Env. Sci., 27, 247-251, 2003.

Overland, J. E., Bhatt, U., Key, J., Liu, Y., Walsh, J., and Wang, M.: Temperature and clouds, Arctic Report Card, edited by: RichterMenge, J., Jeffries, M. O., and Overland, J. E., NOAA Rep. 1119, available at: http://www.arctic.noaa.gov/reportcard, 2011.

Pepin, N. C. and Lundquist, J. D.: Temperature trends at high elevations: Patterns across the globe, Geophys. Res. Lett., 35, L14701, doi:10.1029/2008GL034026, 2008.

Ramage, J. M. and Isacks, B. L.: Determination of melt-onset and refreeze timing on southeast Alaskan icefields using SSM/I diurnal amplitude variations, Ann. Glaciol., 34, 391-398, 2002.

Ramage, J. M., McKenney, R. A., Thorson, B., Maltais, P., and Kopczynski, S. E.: Relationship between passive microwavederived snowmelt and surface-measured discharge, Wheaton River, Yukon, Hydrol. Proc., 20, 689-704, 2006.

Rangwala, I. and Miller, J. R.: Climate change in mountains: a review of elevation-dependent warming and its possible causes, 
Clim. Change, 114, 527-547, doi:10.1007/s10584-012-0419-3, 2012.

Rawlins, M. A., McDonald, K. C., Frolking, S., Lammers, R. B., Fahnestock, M., Kimball, J. S., and Vörösmarty, C. J.: Remote sensing of snow thaw at the pan-Arctic scale using the SeaWinds scatterometer, J. Hydrol., 312, 294-311, 2005.

Regonda, S. K., Rajagopalan, B., Clark, M., and Pitlick, J.: Seasonal cycle shifts in hydroclimatology over the western United States, J. Climate, 18, 372-384, 2004

Rice, R., Bales, R. C., Painter, T. H., and Dozier, J.: Snow water equivalent along elevation gradients in the Merced and Tuolumne River basins, Sierra Nevada, Water Resour. Res., 47, W08515, doi:10.1029/2008GL034026, 2011.

Rouse, W. R., Douglas, M. S. V., Hecky, R. E., Hershey, A. E., Kling, G. W., Lesack, L., Marsh, P., McDonald, M., Nicholson, B. J., Roulet, N. T., and Smol, J. P.: Effects of climate change on the freshwaters of Arctic and Subarctic North America, Hydrol. Proc., 11, 873-902, 1997.

Schwartz, M. D., Ahas, R., and Aasa, A.: Onset of spring starting earlier across the North Hemisphere, Glob. Change Biol., 12, 343-351, 2006.

Semmens, K. A, Ramage, J., Bartsch, A., and Liston, G. E.: Early snowmelt events: detection, distribution, and significance in a major sub-arctic watershed, Environ. Res. Lett., 8, 014020, doi:10.1088/1748-9326/8/1/014020, 2013.

Serreze, M. C., Walsh, J. E., Chapin III, F. S., Osterkamp, T., Dyurgerov, M., Romanovsky, V., Oechel, W. C., Morison, J., Zhang, T., and Barry, R. G.: Observational evidence of recent change in the northern high-latitude environment, Clim. Change, 46, 159-207, 2000.

Shakesby, R. A. and Doerr, S. H.: Wildfire as a hydrological and geomorphological agent, Earth-Science Rev., 74, 269-307, 2006.

Stewart, I. T., Cayan, D. R., and Dettinger, M. D.: Changes toward earlier streamflow timing across Western North America, J. Climate, 18, 1136-1155, 2005.

Stone, R. S., Dutton, E. G., Harris, J. M., and Longenecker, D.: Earlier spring snowmelt in northern Alaska as an indicator of climate change, J. Geophys. Res., 107, 4089, doi:10.1029/2000JD000286, 2002.

Stroeve, J., Maslanik, J., and Xiaoming, L.: An intercomparison of DMSP F11- and F13-derived sea ice products, Remote Sens. Environ., 64, 132-152, 1998.

Takala, M., Luojus, K., Pulliainen, J., Derksen, C., Lemmetyinen, J., Karna, J. P., Koskinen, J., and Bojkov, B.: Estimating northern hemisphere snow water equivalent for climate research through assimilation of space-borne radiometer data and ground-based measurements, Remote Sens. Environ., 115, 3517-3529, 2011.

Tedesco, M.: Snowmelt detection over the Greenland ice sheet from SSM/I brightness temperature daily variations, Geophys. Res. Lett., 34, L02504, doi:10.3189/172756501781831738, 2007.

Tedesco, M., Brodzik, M., Armstrong, R., Savoie, M., and Ramage, J.: Pan arctic terrestrial snowmelt trends from spaceborne passive microwave data and correlation with the AO, Geophys. Res. Lett., 36, L21402, doi:10.1029/2009GL039672, 2009.
Tomasino, M. and Valle, F. D.: Natural climatic changes and solar cycles: an analysis of hydrological time series, Hydrol. Sci. J., 45, 477-489, 2000.

Trujillo, E., Molotch, N. P., Goulden, M. L., Kelly, A. E., and Bales, R. C.: Elevation-dependent influence of snow accumulation on forest greening, Nature Geosci., 5, 705-709, doi:10.1038/NGEO1571, 2012.

Ulaby, F. T., Moore, R. K., and Fung, A. K.: Microwave Remote Sensing: Active and Passive, Vol. III: From Theory to Applications, Artech House: Dedham, 1986.

US Geological Survey: National Water Information System data available on the World Wide Web (Water Data for the Nation), available at: http://waterdata.usgs.gov/usa/nwis/uv?site no=_15485500 (last accessed March 10 2012), 2001.

Walvoord, M. A. and Striegl, R. G.: Increased groundwater to stream discharge from permafrost thawing in the Yukon River basin: Potential impacts on lateral export of carbon and nitrogen, Geophys. Res. Lett., 34, L12402, doi:10.1029/2009GL039672, 2007.

Wang, L., Sharp, M., Brown, R., Derksen, C., and Rivard, B.: Evaluation of spring snow covered area depletion in Canadian Arctic, NOAA snow charts, Remote Sens. Environ., 95, 453-63, 2005.

Wang, L., Derksen, C., and Brown, R.: Detection of pan-arctic terrestrial snowmelt from QuikSCAT, 2000-2005, Remote Sens. Environ., 112, 3795-3805, 2008.

Wang, L., Wolken, G. J., Sharp, M. J., Howell, S. E. L., Derksen, C., Brown, R. D., Markus, T., and Cole, J.: Integrated panArctic melt onset detection from satellite active and passive microwave measurements, 2000-2009, J. Geophys. Res., 116, D22103, doi:10.1029/2009GL039672, 2011.

Westerling, A. L., Hidalgo, H. G., Cayan, D. R., and Swetnam, T. W.: Warming and earlier spring increase western US forest wildfire activity, Science, 313, 940-943, 2006.

Woo, M. K. and Thorne, R.: Snowmelt contribution to discharge from large mountainous catchment in subarctic Canada, Hydrol Proc., 20, 2129-2139, 2006.

Woo, M. K., Thorne, R., Szeto, K., and Yang, D.: Streamflow hydrology in boreal region under the influences of climate and human interference, Phil. Trans. R. Soc. B, 363, 2251-2260, 2008.

Yang, D., Kane, D. L., Hinzman, L. D., Zhang, X., Zhang, T., and Ye, H.: Siberian Lena River hydrologic regime and recent change, J. Geophys. Res., 107, 4694, doi:10.1029/2009GL039672, 2002.

Yang, D., Zhao, Y., Armstrong, R., and Robinson, D.: Yukon River streamflow response to seasonal snow cover changes, Hydrol. Proc., 23, 109-121, 2009.

Zhang, Z., Dehoff, A. D., and Pody, R. D.: New approach to identify trend pattern of streamflows, J. Hydrol. Engin., 15, 244-248, 2010 . 